\title{
THE ENRON COLLAPSE AND CRIMINAL LIABILITIES OF AUDITORS AND LAWYERS FOR DEFECTIVE PROSPECTUSES IN THE UNITED STATES, AUSTRALIA AND CANADA: A REVIEW
}

\author{
S.M. Solaiman ${ }^{*}$
}

\begin{abstract}
A lack of uniformity in laws regulating professionals such as auditors and lawyers in relation to defective prospectuses exists across nations around the world. Securities legislation of some jurisdictions clearly imposes criminal liabilities for defective prospectuses on professionals along with directors and promoters of the issuer of securities. But the laws of some other countries are ambiguous in this regard. Such an ambiguity is present in the securities legislation of the United States, Australia and Canada. Their legislation does not categorically name the persons who should be criminally liable for a defective prospectus; nonetheless auditors and lawyers are sometimes caught by virtue of judicial interpretations of those vague legal provisions. Even though they could be on the hook under such interpretations, legislation provides a wide range of defences that facilitate escaping liabilities by offenders at the expense of the integrity of the market. Regarding sanctions, although the term of imprisonment is identical in all these three jurisdictions, pecuniary penalties significantly vary after the recent reforms triggered by some spectacular corporate bankruptcy taking place especially in the U.S. and Australia. Most importantly, the post-Enron reforms explicitly amend the laws governing secondary securities markets, and therefore their application to defective prospectuses is questionable except for the Canadian reforms. If the post-Enron reforms do not really touch the prospectus liability regimes in the U.S. and Australia, it can be said that the lawmakers have ignored their primary securities markets. If this is so, it would be an unwise policy to wait for an Enron-type disaster to occur in the IPO market for stimulus to initiate reforms addressing professional malpractices in the preparation of prospectuses. If not, the law should make it clear before it is too late.
\end{abstract}

* Faculty of Law, University of Wollongong, NSW 2522, Australia. 


\section{INTRODUCTION}

In the aftermath of several recent appalling corporate failures in some developed countries, ${ }^{1}$ the concern for the regulation of accountants ${ }^{2}$ has gained a fresh stimulus, which is evident in the current academic debates and corresponding legislative reforms being made in the United States, Australia and Canada. ${ }^{3}$ Investor confidence is the Holy Grail of the successful operation of securities markets around the world and adequate measures for investor protection are central to this confidence in the market.

Every jurisdiction adopts certain strategies for protecting the investing public from abusive practices in securities markets. Mandatory disclosure requirement comes ahead of all other strategies. ${ }^{4}$ The creation and maintenance of investor confidence in a market are greatly dependent on the integrity of the market, which is demonstrated through the timely and credible disclosure of material facts facilitating informed investment decisions. Disclosures in prospectuses aim to eliminate information asymmetry between corporations and their prospective investors. This elimination may be possible only through full, fair and timely disclosures of material facts and their utilisation by the investing public. But in reality, the notion of ensuring full and fair disclosure may seem to be largely illusive, perhaps owing to the fact that "problems at which modern securities regulation is directed are as old as the cupidity of sellers and the gullibility of buyers,", as observed by Professor Louis Loss, the intellectual father of securities law in the United States. ${ }^{6}$

1. For example, Enron and WorldCom collapses in the U.S. and HIH and One Tel collapses in Australia. For analytical discussions of these collapses, see Jennifer G. Hill, Regulatory Responses to Global Corporate Scandals, 23 Wis. InT’L L.J. 367 (2005); Jerry W. Markham, Accountants Make Miserable Policemen: Rethinking the Federal Securities Laws, 28 N.C. J. InT'L L. \& Com. Reg. 725 (2003); Lawrence A. Cunningham, The Sarbanes-Oxley Yawn: Heavy Rhetoric, Light Reform (And It Just Might Work), 35 Conn. L. Rev. 917 (2003); Roman Tomasic, Current Development and Notes: Corporate Collapse, Crime and Governance-Enron, Anderson and Beyond, 14 AustL. J. CoRP. L. 1 (2002).

2. The term "accountants" in this study refers to those who are certified public accountants and perform audit services for companies willing to go public.

3. See Anita Indira Anand, Shareholder Isolation and the Regulation of Auditors, 54 U. TORONTO L.J. 1, 1 (2004); H. Garfield Emerson \& Geoff A. Clarke, Address at the 3rd Annual Directors' Governace Summit: Bill 198 and Ontario's Securities Act: Giving Investors and The OSC Added Muscle, available at http://www.fasken.com/WEB/fmdwebsite.nsf/AllDoc/A69604E494A1AD7685256DDD0058D3E3/ \$File/BILL198.PDF!OpenElement. New reforms will be introduced later in this paper.

4. Reinier Kraakman et al., The Anatomy of Corporate Law-A Comparative and FunCtional APPROACH 212 (2004).

5. Louis Loss \& Joel Seligman, Fundamentals of Securities Regulation 1 (2d ed. 1988).

6. Louis Loss, Emeritus Law Professor, Securities Law Specialist, Dies at 83, Harv. Univ. GazetTe, Dec. 21, 2005, available at http://www.news.harvard.edu/gazette/1998/01.15/LouisLoss 
Sometimes it is clearly admitted that the eradication of securities fraud and manipulation is impossible. ${ }^{7}$ However, corporate abusive practices may be minimised to a reasonable extent by effective regulation of market players. With this end in view, securities regulation commenced in the early eighteenth century; ${ }^{8}$ and the International Organisation of Securities Commissions (IOSCO) set out the objectives of securities regulation as: protecting investors, ensuing market fairness and efficiency and reducing systemic risks. ${ }^{9}$ Despite some instances of regulatory failures in securities markets, the regulation of market players is now considered essential for investor protection, ${ }^{10}$ and criminal sanctions now play a pivotal role in policing corporations. ${ }^{11}$

It has been argued that investors have the right to receive accurate disclosures and the persons who are at fault in infringing on that right "should be held liable, whether they are primary or secondary actors." 12 In addressing the post-Enron situation, the United States Congress has explained that auditors play the role of guardian of the securities market, ${ }^{13}$ and lawmakers were arguably forced to enact new legislation predominantly concerning accounting professionals in order to protect investors from the market misfeasance in the wake of the collapse of corporate giants. ${ }^{14}$ Referring to the corporate collapses in Australia in the 1980s, Bosch (the former chairman of the Australian securities watchdog) observed that auditors must be blamed for misleading or outrageous disclosure by corporations. ${ }^{15}$ There has been a demand for enhanced liability of accountants in Canada following the effects of the Enron incident on domestic markets. ${ }^{16}$ Legislative initiatives have been

Emerit.html.

7. NeilMohindra, Securities Market Regulation in Canada, Fraser InSt. CRITICAL Issues Bull., Apr. 2002, at 36, available at http://www.fraserinstitute.ca/shared/readmore.asp?sNav=pb\&id=317.

8. See Robert L. Knauss, A Reappraisal of the Role of Disclosure, 62 Мich. L. Rev. 607, 610

9. Int'l Org. of Sec. Comm'ns, Objectives and Principles of Securities Regulation i (2003), available at $\mathrm{http} / / / \mathrm{www}$. iosco.org/library/pubdocs/pdf/IOSCOPD154.pdf.

10. Mary M. Wynne, Comment, Primary Liability Amongst Secondary Actors: Why the Second Circuit's "Bright Line" Standard Should Prevail, 44 St. Louis U. L.J. 1607, 1608 (2000).

11. Alan C. Michaels, Fastow and Arthur Andersen: Some Reflections on Corporate Criminality, Victim Status, and Retribution, 1 OHIO ST. J. CRIM. L. 551, 551 (2004).

12. Wynne, supra note 10 , at 1607.

13. David F. Birke, The Toothless Watchdog: Corporate Fraud and the Independent Audit-How Can the Public's Confidence Be Restored?, 58 U. MiAmi L. Rev. 891, 916 (2004).

14. Id. at 891-92.

15. R. Webb, Auditors Must Share Blame-Bosch, Austl. Fin. Rev. June 11, 1991.

16. For a detailed discussion of auditor liability in Canada, see Grace Hession, Auditor Independence and Liability in Canada: Are We Ready for Third Party Liability?, 36 U. Brit. Columb. 
undertaken in many countries for increasing and widening accountants' liability for defective disclosures with a core assumption that fair financial reporting could have prevented those failures and thereby protected investors and other stakeholders. This article deals with the criminal liabilities of auditors and lawyers for "defective prospectuses" 17 in the United States Australia and Canada. ${ }^{18}$ It focuses on the similarities and differences between these three jurisdictions in respect of provisions concerning criminal liabilities of auditors and lawyers under securities law with special reference to postEnron legal reforms, defences available to this liability and penalties applicable to prospectus criminal offences.

\section{Methodology and Limitations}

The U.S., Australia and Canada have been chosen for this comparative review because of their similarities in legal traditions, regulatory philosophies and reform measures undertaken following the Enron collapse. They belong to the common law family, follow a mandatory disclosure regime and have enacted new legislation to address the regulatory problems relevant to the post-Enron securities market. Although securities regulation in all of these federations was initially effected at state or provincial level, some significant changes have taken place in their regulatory approach over the past few decades. The U.S. in 1934 introduced federal regulation ${ }^{19}$ under the Securities Act 1933 (SA'33) and Securities Act 1934 (SEA'34) alongside the pre-existing state regulation which is effected under blue sky laws. ${ }^{20}$ Australia completely

L. REV. 575 (2003).

17. For the purposes of this study, the phrase "defective prospectus" means a prospectus which contains misleading and deceptive statements or omits to state a material fact which was required to be stated under the relevant law.

18. The reasons for choosing Ontario jurisdiction from Canada will be discussed in the methodology section below.

19. Although the Securities Act was enacted in 1933, the U.S. Securities and Exchange Commission was established under the Securities Exchange Act 1934.

20. Blue Sky Laws as described by the U.S. Securities and Exchange Commission:

Every state has its own securities laws - commonly known as "Blue Sky Laws"- that are designed to protect investors against fraudulent sales practices and activities. While these laws can vary from state to state, most states [sic] laws typically require companies making small offerings to register their offerings before they can be sold in a particular state. The laws also license brokerage firms, their brokers, and investment adviser representatives.

U.S. SeC. Ехсн. Сомm'N, Blue Sky Laws, available at http://www.sec.gov/answers/bluesky.htm. For details of the blue sky laws, see Jonathan R. Macey \& Geoffrey P. Miller, Origin of the Blue Sky Laws, 70 TEx. L. Rev. 347 (1991); Conrad G. Goodkind, Blue Sky Law: Is There Merit in the Merit Requirements?, 1976 Wis. L. Rev. 79. 
abolished its state regulation, replacing with federal regulation of securities through the establishment of the Australian Securities and Investment Commission (ASIC) in 1991. ${ }^{21}$ Although there has been an effort to unify securities law and regulation in Canada, it is still following securities regulation at province and territory levels. ${ }^{22}$ However, Canadian Securities Administrators (CSA), a forum of Canadian securities regulators, has been "providing for regulatory cooperation, harmonisation of regulatory standards, coordination of rules and dealing with regulatory issues of common interest." 23 The CSA is publicly known as the "virtual" national regulator although no one stop securities regulator exists in Canada. ${ }^{24}$ Ontario has been chosen from amongst the 13 jurisdictions in Canada for this paper mainly because it is the largest and most prominent jurisdiction for the purpose of securities regulation in Canada. ${ }^{25}$

Both primary and secondary materials are used in this article. In addition to published materials, some eminent scholars are consulted for the clarity and applicability of recent development in these three jurisdictions.

Criminal liabilities for defective prospectuses are imposed under both securities law and criminal law. This study is concerned with the liabilities under securities law that can be enforced through judicial actions. Administrative actions against prospectus offences and liabilities under criminal law fall beyond this article.

21. The Australian Securities \& Investments Commission (ASIC) is an independent Australian government body which has regulated securities markets since January 1991. Initially called the Australian Securities Commission (ASC), it was renamed as ASIC in July 1998 when its responsibilities were extended to consumer protection in superannuation, insurance and deposit taking. Austl. SeC. \& InV. Comm'N, Aвоut ASIC, available at http://www.asic.gov.au/asic/asic.nsf/byheadline/About+ASIC?opendocument.

22. Mary G. Condon et Al., Securities Law in Canada: Cases and Commentary 112 (2005).

23. Paul Latimer, Securities Regulation-Canadian Lessons for Australian Regulation, 13 AustL. J. CORP. L. 1, 12 (2001).

24. Id.

25. David L. Johnston \& Kathleen Doyle Rockw ell, Canadian Securities Regulation 10 (3d ed. 2003). 
Professionals' Responsibilities Triggering Criminal Liabilities for Defective Prospectuses

\section{Auditors' Responsibilities}

Accountancy is a thriving profession which is able to act as "private gatekeeper" to the capital market. ${ }^{26}$ It has been argued that accountants play a vital role in presenting distorted financial reports of corporations to the public. ${ }^{27}$ The role of auditors is perhaps the most significant of all the various functions performed by accountants in society. ${ }^{28}$ The primary role of an auditor "is to review, analyze, and determine the validity" of the claims intended to be made by his/her client in the prospectus. ${ }^{29}$ More importantly, auditors are sometimes considered to be independent guarantors of truth and fairness in the financial disclosure of corporations. ${ }^{30}$ Generally, auditing of corporate financial statements is intended to show the true financial health of the entity to third parties such as securities regulators, creditors and present and prospective investors through making a fair presentation of the companies' financial affairs. ${ }^{31}$ Consistently, it is a reality in the securities market that investors use the audited financial statements for investment purposes and thereby firms raise capital from the public. ${ }^{32}$ Auditing is thus central to the public confidence in financial disclosures; absent this confidence, "the capital will dry up and the system will be crippled." 33 This is so because an auditor is considered to be an intermediary between firms and investors in respect of corporate financial statements. ${ }^{34}$ In other words,

26. Frank Partnoy, Barbarians at the Gatekeepers: A Proposal for a Modified Strict Liability Regime, 79 Wash. U. L.Q. 491, 491 (2001). (1995).

27. Martin Markovic, Auditors' Criminal Liability: Another Approach, 6 AustL. J. Corp. L. 1, 65

28. Norman S. Johnson \& Ross A. Albert, "Deja Vu All Over Again" The Securities and Exchange Commission Once More Attempts to Regulate the Accounting Profession through Rule 102 (e) of Its Rules of Practice, 1999 Utah L. Rev. 553, 556.

29. Constance Frisby Fain, Accountant Liability, 21 Oнıо N.U. L. REv. 355, 358 (1994); see also Brian K. Kirby \& Thomas L. Davies, Accountant Liability: New Exposure for an Old Profession, 36 S.D. L. REv. 574, 577 (1991).

30. Frank J. Macchiarola, The Accountant's Liability Controversy, 1988 Colum. Bus. L. Rev. 177, 179 .

31. Thomas L. Gossman, The Fallacy of Expanding Accountants' Liability, 1988 Colum. Bus. L. Rev. 213, 213 (citing David N. Ricchiute, Accounting Concept and Standards 6 (1982)).

32. Hession, supra note 16 , at 617 .

33. $I d$.

34. Gossman, supra note 31, at 213-14. 
auditors are theoretically "an arm's-length third party" and they are supposed to work beyond any undue management pressures. ${ }^{35}$

Therefore, auditors have an extremely significant role to play in making reliable corporate disclosures to the public in the market for initial public offerings (IPOs). In appreciation of that role, suits for professional misconduct against accountants have amplified dramatically over the past two decades, ${ }^{36}$ where they are often sued by third parties who suffered loss by relying upon the audited financial statements of companies. ${ }^{37}$ Although the victims of a corporate failure may sue others such as directors, lawyers, and underwriters, accountants are especially targeted for lawsuits where the failed entity recently received a positive audit report. ${ }^{38}$

\section{Lawyers' Responsibilities}

Lawyers are primarily responsible for the verification of the legal requirements for the prospectus although they get involved in the process of an IPO at a much later stage than that of the auditors. ${ }^{39}$ However, both lawyers and auditors are generally regarded as "gatekeepers." Coffee defines the term "gatekeeper" as "independent professionals who serve investors by preparing, verifying, or assessing the disclosures that they receive." 40 Regarding the function of securities lawyers, he maintains that they provide an opinion to the underwriter that the prospectus contains all material information in relation to the issue and issuer. ${ }^{41} \mathrm{He}$ argues that securities lawyers perform multiple roles such as: advocate, engineer and gatekeeper. ${ }^{42}$ $\mathrm{He}$ asserts that "the attorney is the field marshall of the disclosure process." 43 In discussing professionals' roles in the context of Enron, Rhode and Paton argue that lawyers "passively acquiesce in client fraud." 44

35. See Anand, supra note 3 , at 5 .

36. See James H. Thompson \& Laurie J. Henry, Professional Liability Insurance: Go Bare or Not?, 172 J. АсСт. 111, 111 (1991).

37. See David A. Olsen, Let's Have Fair Play for the CPA, N.Y. Times, Dec. 29, 1991, at F13.

38. Id.

39. Randolph P. Beatty \& Ivo Welch, Issuer Expenses and Legal Liability in Initial Public Offerings, 39 J.L. \& ECON. 545, 549 (1996).

40. John C. Coffee Jr., The Attorney as Gatekeeper: An Agenda for the SEC, 103 CoLum. L. Rev. 1293, 1296 (2003).

41. Id. at 1296-97.

42. For details of these roles, see id. at 1302-14. See also Manning Gilbert Warren III, The Primary Liability of Securities Lawyers, 50 SMU L. REv. 383 (1996).

43. Coffee, supra note 40, at 1312.

44. Deborah L. Rhode \& Paul D. Paton, Lawyers, Ethics, and Enron, 8 Stan. J.L. Bus. \& Fin. 9 
In brief, lawyers provide advice to issuers of securities on the legal requirements of disclosures in prospectuses and certify the compliance with the relevant law. Investors are believed to buy securities based on those disclosures. At the same time lawyers are also responsible to make the issuer aware of legal requirements and consequences of noncompliance. Therefore they play a significant role in respect of an IPO and they could be held liable for inaccurate advice. ${ }^{45}$

\section{Rationale for Professionals' Criminal Liability for Defective Prospectuses}

\section{Rationale for Auditors' Criminal Liability}

The rationale of the imposition of liability on outside professionals such as auditors and lawyers was debated extensively in the early 1990s. ${ }^{46}$ But opponents' arguments could not prevent accountants' liability for defective disclosure by corporations and therefore proponents' arguments eventually prevail. ${ }^{47}$ Auditors' liability is attributable to their "substantial participation" or "intricate involvement" in the preparation of a prospectus. ${ }^{48}$ The U.S. Supreme Court in Central Bank v. First Interstate Bank noted that secondary actors in the securities market may be held liable as primary violators where "any person or entity, including a lawyer, accountant, or bank, who employs a manipulative device or makes a material misstatement (or omission) on which a purchaser or seller of securities relies may be held liable as primary violator. . . ."49 Langevoort argues that outside professionals such as accountants and lawyers often have much influence over corporate disclosures, in terms of both forms and contents, which can deceive investors, and therefore they should be made liable for defective disclosure even though

(2002).

45. See Schneider v. Traweek, Fed. Sec. L. Rep. P 95,419, 1990 WL 132716, at*1 (C.D. Cal. July 31,1990$)$.

46. For a discussion of such a debate, see Melissa Harrison, The Assault on the Liability of Outside Professionals: Are Lawyers and Accountants Off the Hook?, 65 U. CIN. L. Rev. 473, 477-80 (1997).

47. See Joel Seligman, The Implications of Central Bank, 49 Bus. LAw. 1429, 1442 (1994).

48. See, e.g., In re Software Toolworks Inc. Litig., 50 F.3d 615 (9th Cir. 1994); In re ZZZZ Best Sec. Litig., 864 F. Supp. 960 (C.D. Cal. 1994); In re MTC Elec. Tech. Shareholders Litig., 898 F. Supp. 974 (E.D.N.Y. 1995); Wright v. Ernst \& Young, 152 F.3d 169 (2d Cir. 1998).

49. 511 U.S. 164, 191 (1994). Although this observation was made under $\S 10(b)$ of the Securities Exchange Act 1934 and Rule 10b-5 which applies to the second ary market, the observation should be still relevant to the disclosure in prospectuses in respect of imposing liability on individuals. 
their roles may be sometimes less direct. ${ }^{50}$ Although courts had difficulty in the past in resolving the issue of accountants' liability for a securities transaction, the modern judicial pronouncements clearly recognise that "if an accountant had fraudulently certified materially misleading financial statements that were placed in a prospectus distributed to the investing public, a court would find a sufficient connection with the securities transaction to warrant liability." ${ }^{, 1}$ This liability is of a primary nature. This is because an audit report is argued to be an actual representation and therefore auditors are exposed to primary liability for defective disclosures, although other aspects of the functions of a certified public accountant such as the preparation of financial statements may trigger secondary liability. ${ }^{52}$

In line with the current arguments for accountants' or auditors' liabilities, Tomasic, by referring to the wave of corporate collapse of the 1980s, observes that they (auditors) are easily blamed for corporate failures. ${ }^{53}$ Now the situation has become even worse. Although auditors have for a long time been held liable for defective prospectuses, their statutory liabilities have not yet been clearly articulated in the legislation of many countries. As a result, their conviction largely depends upon the judicial approach to the interpretation of a particular offence committed in relation to prospectus disclosures.

\section{Rationale for Lawyers' Criminal Liability}

Securities regulation involves complicated laws and procedures; given that complexity, lawyers' role concerning an IPO is critical. ${ }^{54}$ Failure of lawyers to perform their role properly ultimately helps the issuer commit

50. Donald C. Langevoort, Words From on High about Rule 10b-5; Chiarella's History: Central Bank's Future, 20 DEL. J. CORP. L. 865, 891-92 (1995).

51. Timothy M. Metzger, Comment, Abandoning Accountant's Liability for Aiding and Abetting 10b-5 Securities Fraud, 87 Nw. U. L. Rev. 1374, 1405 (1993). For the application of Rule 10b-5 to prospectus disclosures and holding accountants liable under this Rule, see SEC v. Seaboard Corp., 677 F.2d 1301, 1311-12 (9th Cir. 1982). See also SEC v. Wills, 472 F. Supp. 1250, 1269-71 (D.D.C. 1978); Ernst \& Ernst v. Hochfelder, 425 U.S. 185 (1976).

52. Lawrence R. Bard, A Distinct-Responsibility Approach to Accountants' Primary Liability Under Rule 10b-5, 61 Geo. Wash. L. Rev. 193, 220 (1992). With respect to fraudulent activity such as misrepresentations, omissions and schemes to defraud under securities law ( $\S 10(\mathrm{~b})$ of the Security Exchange Act of 1934), the judiciary recognizes two types of civil liability: primary and secondary. Primary liability is imposed on those who directly violate securities law, whilst secondary liability is ascribed to those who provide substantial assistance to the direct violators. See IIT v. Cornfeld, 619 F.2d 909, 922 (2d Cir. 1980).

53. Roman Tomasic, Auditors and the Reporting of Illegality and Financial Fraud, 20 Aust. Bus. L. REV. 198, 198 (1992).

54. Warren, supra note 42 , at 387. 
offences. ${ }^{55}$ This is so because the issuer could not have issued the prospectus to the public had the lawyer warned the issuer of defects in the prospectus. Thus lawyers are in a position to prevent the issuer from going public with a defective prospectus. ${ }^{56}$ Hence lawyers should be held liable for defective prospectuses and they are sometimes considered primary violators for material misstatements or omissions included in prospectuses. ${ }^{57}$

It is also argued that professionals such as lawyers, auditors and underwriters may be held liable for mere participation in the process of prospectus preparation, because their participation "can provide an implicit certification" to the investing public about the accuracy of disclosures. ${ }^{58}$ Similarly, in dealing with a case involving deceptive conduct in connection of the sale of securities, the U.S. District Court for the Central District of California held that simple participation of professionals might trigger liability. ${ }^{59}$

Auditors and lawyers are exposed to both civil and criminal liabilities for their faults committed in providing their professional service. ${ }^{60}$ Historically a debate emerged regarding their civil liability, based on the doctrine of privity of contract, that this liability was limited to parties to the contract in exclusion of third parties who became victim of the accountants' or lawyers' wrongs. ${ }^{61}$ That notion has changed over time ${ }^{62}$ and professionals' fiduciary duty of care has been extended by the judiciary to non-clients third parties who are adversely affected by their professional services. ${ }^{63}$ Even some jurisdictions have extended this duty to the public in general. ${ }^{64}$ In so doing the

55. Harrison, supra note 46, at 537.

56. See Lewis D. Lowenfels \& Alan R. Bromberg, Controlling Person Liability Under Section 20(a) of the Securities Exchange Act and Section 15 of the Securities Act, 53 Bus. Law. 1 (1997). Section 15 of the Securities Act 1933 (US) is applicable to $\S \S 11$ and 12, which imposes liability on various persons including current and future or prospective directors of the issuers of IPOs. Hence, the controlling persons' liability as set forth in $\S 15$ is quite relevant.

57. See generally Breard v. Sachnoff \& Weaver Ltd., 941 F.2d 142 (2d Cir. 1991); Molecular Tech. Corp. v. Valentine, 925 F.2d 910, 913-19 (6th Cir. 1991).

58. Royce de R. Barondes, Professionalism Consequences of Law Firm Investments in Clients: An Empirical Assessment, 39 AM. Bus. L.J. 379, 382 (2002).

59. See In re ZZZZ Best Co. Sec. Litig., 864 F. Supp. 960, 970 (C.D. Cal. 1994).

60. Gossman, supra note 31, at 215.

61. Kirsten L. Thompson, Liability of Professionals, Officers, and Directors: Annual Survey, 28 TORT \& INS. L.J. 376, 377 (1993).

62. Perhaps the New York Supreme Court first broke the English tradition of the privity of contract in Schermerhorn v. Vanderheyden, 1 Johns 116 (1806).

63. Thompson, supra note 61, at 377-78. See also New Orleans Sheet Metal Worker's v. ABC Ins. Co., 599 So. 2 d 868 (La. App. 4 Cir. 1992).

64. Id. at 376 . 
courts have adopted the principle of third party beneficiary rights. Therefore, professionals are civilly liable to the third party beneficiaries of their report in the United Sates, Australia ${ }^{65}$ and Canada. ${ }^{66}$ In this regard, the House of Lords in Hedley Byrne \& Co. v. Heller \& Partners Ltd. pronounced that professionals owe a duty of care to their clients and also to the third parties and therefore are civilly liable to them. ${ }^{67}$ Australia adopted this view, evident in the judgments in several recent cases by the High Court of Australia. ${ }^{68}$

Thus auditors and lawyers are now exposed to an extended civil liability regime. However, the doctrine of privity is not quite relevant to the discussion of this article because criminal liability is premised on the wrong committed against the society or state as a whole, rather than against any individuals.

To distinguish between these two, it can be briefly described that civil liability aims to compensate the persons who incurred loss or damage by relying on audited financial statements included in a prospectus; whereas criminal liabilities purport to save the society by deterring the delinquent accountants. Criminal liabilities are imposed by statutes such as securities legislation and the law of crimes; whilst civil liabilities are ascribed under both the law of tort and statutes such as contract law and securities law.

Regarding criminal liability, since the decision of the United States Supreme Court in Central Bank of Denver v. First Interstate Bank of Denver, ${ }^{69}$ accountants and lawyers are no longer an aider or abettor for the violation of securities law. However they can still be prosecuted as aider or abettor under criminal law..$^{70}$ Auditors and lawyers can be prosecuted as principal violators of securities law as will be discussed below.

65. San Sebastian Proprietary Ltd. v. Minister Administering the Envtl. Planning \& Assessment Act 1979 (1986) 162 C.L.R. 340, 357 (Austl.); Hawkins v. Clayton, (1988) 164 C.L.R. 539, 580 (Austl.); Esanda Fin. Corp. v. Peat Marwick Hungerfords, (1997) 188 C.L.R. 241, 265 (Austl.).

66. Hercules Mgmt. v. Ernst \& Young, (1997) 2 S.C.R. 165 (Can.); Haig v. Bamford, (1976) 1 S.C.R. 466 (Can.).

67. (1964) A.C. 465,486 (U.K.)

68. See, e.g., Esanda Fin. Corp. v. Peat Marwick Hungerfords, (1997) 188 C.L.R. 241, 265; Edwards Karwacki Smith \& Co. v. Jacka Nominees Proprietary Ltd., (1994) 15 A.C.S.R. 502 (Austl.); Meadow Gem Proprietary Ltd. v. ANZ Ex'rs \& Tr. Co., (1996) 2 V.R. 26 (Austl.).

69. 511 U.S. 164, 191 (1994).

70. Larry Catá Backer, The Duty to Monitor: Emerging Obligations of Outside Lawyers and Auditors to Detect and Report Corporate Wrongdoing Beyond the Federal Securities Laws, 77 ST. JoHN's L. REV. 919, 984 n.285 (2003). 


\section{Introduction to Post-Enron Legal Reforms}

The most prominent piece of legislation has been enacted following the Enron effects in the U.S. In 2002, the Congress passed the Public Company Accounting Reform and Investor Protection Act of 2002, popularly known as Sarbanes-Oxley Act 2002 (SOX'02) in order to heighten transparency in the corporate sector. According to the Chairman of the U.S. SEC, the SOX'02 is "the most significant piece of securities legislation" in the past 70 years. ${ }^{71}$ The U.S. President himself proclaimed that " $[\mathrm{m}] \mathrm{y}$ administration pressed for greater corporate integrity. A united Congress has written it into law. And today I sign the most far-reaching reforms of American business practices since the time of Franklin Delano Roosevelt." 72

The SOX'02 was legislated in "response to the massive accounting frauds at companies," and it concentrated on "improving the accounting oversight of publicly traded companies." 73 Perhaps the greatest emphasis has been given under the SOX'02 to addressing corporate accounting issues in a bid to protect investors and regain public confidence in the market. Under section 101(a), the SOX'02 creates the Public Company Accounting Oversight Board (PCAOB), a new federal agency to oversee accounting firms that perform corporate audits. A set of new rules and procedures for auditors and issuers has also been included in this legislation. ${ }^{74}$ It also requires certification of accuracy of companies' financial statements on a continuing basis by the CEOs and chief financial officers (CFOs) of a reporting company; failure of which triggers enhanced criminal sanctions. ${ }^{75}$

Section 307 of the SOX'02 specifically imposes responsibility on lawyers. It empowers the SEC to issue rules "setting forth minimum standards of professional conduct for attorneys appearing and practicing before the Commission in any way in the representation of issuers." An attorney under this section is required "to report evidence of material violation of securities

71. William H. Donaldson, Chairman, U.S. Sec. and Exch. Comm'n, U.S. Capital Markets in the Post-Sarbanes-Oxley World: Why OurMarkets Should Matter to Foreign Issuers (Jan. 25, 2005), available at http://www.sec.gov/news/speech/spch012505whd.htm.

72. Peter L. Welsh, Sarbanes-Oxley and the Cost of Criminalization, 8 Sec. Litig. \& Reg. Rep. 20, 1 (2003).

73. Shannon Rose Selden, Fighting Fraud on Faith: Federal Securities Regulation and THE Limits OF Disclosure 62 (2005), available at http://www.bepress.com/expresso/eps/746.

74. Sarbanes-Oxley Act $2002 \S 101$ (a), 15 U.S.C. $§ 7211$ (2002).

75. For a brief discussion of the requirements under Sarbanes-Oxley Act 2002, see JoHn C. CofFEe, Jr. \& Joel Seligman, Securities Regulation: Cases and Materials 2-39 (9th ed. 2005); Backer, supra note 71 , at $939-40$. 
law, or fiduciary duty or similar violation by the company or any agent thereof." Lawyers should submit their reports to either the chief legal counsel or the CEO or the equivalent thereof as required under section 307(1). Making such a report alone does not relieve lawyers from their obligations. Section 307(2) provides that if the person who receives the report does not act properly on the evidence reported, lawyers are required to report further "to the audit committee of the board of directors of the issuer or to another committee of the board of directors comprised solely of directors not employed directly or indirectly by the issuer, or to the board of directors." A failure in making such a report will eventually make the attorney liable both civilly and criminally.

The SOX'02 amends the provisions of the SEA'34, the basic legislation governing the secondary securities market in the U.S., whilst the primary market is governed under, inter alia, the SA'33. It is not clear why the SOX'02 did not change any provision of the SA'33. One reason may be that the scandals that tempted the Congress to make new law took place in the U.S. secondary market. Whatever may be the reason, its silence about the amendment to the SA'33 generates doubts whether this legislation applies to a defective prospectus which contains audited financial statements and an audit report to that effect. The intent of the Congress in this regard is not clear and it seems that "the courts are left to divine Congress's ultimate intent." Although a case reference of its application to a defective prospectus is yet to be found, some experts in U.S. securities law are of the opinion that the SOX'02 may be applicable to defective prospectuses in some respects. Relying on those expert opinions, we will assume for this study that the SOX'02 applies to defective prospectuses although it is still uncertain. ${ }^{77}$ Penal provisions of this legislation will be discussed in later appropriate sections from relevant aspects.

The Corporate Law Economic Reform Program (Audit Reform and Corporate Disclosure) Act 2004 (CLERPA'04) is considered to be the Australian equivalent of the SOX' $02 .^{78}$ This law was legislated following the

76. Erica Gann, Note, Judicial Action in Retrograde: The Case for Applying Section 804 of the Sarbanes-Oxley Act to AllFraud Actions under the Securities Laws, 72 U. CIN. L. REv. 1043, 1059 (2004).

77. For arguments in favour of its application to cases under the SA'93, see $i d$. (dealing with only limitation issue and courts did not agree with those arguments as I have been advised through some personal contact. Experts whose opinions have been gathered through personal communications are not mentioned at this stage.).

78. The Corporate Law Economic Reform Program (Audit Reform and Corporate Disclosure) Act 2004, available at http://scaleplus.law.gov.au/html/comact/browse/TOCN.htm, considerably deals with the regulation of auditors and auditing of companies, and continuing disclosure relevant to the secondary 
debate over the regulation of auditors and corporate governance systems ${ }^{79}$ generated by the concentrated period during 2001-2002 of corporate collapses in the U.S. and Australia as alluded to earlier. The objective of the CLERPA' 04 as stated by the government is "to ensure that business regulation is consistent with promoting a strong and vibrant economy and provides a framework which assists business in adapting to change." ${ }^{\prime 80}$ The CLERPA'04 particularly amended the requirements of publicly listed companies and deals considerably with, amongst other things, the regulation of auditors and auditing of companies, continuing corporate disclosure which is relevant to the secondary securities market. Similar to the SOX'02, the applicability of the CLERPA'04 to the prospectus disclosure requirements is questionable. However, in response to personal contact with this writer, experts of Australian securities law are of the view that the CLERPA'04 does not apply to prospectus disclosures and the prospectus regime was adequately amended by the Corporate Law Economic Law Reform Program Act 1999 (CLERPA'99) which was given effect from 13 March 2000.

The CLERPA'04 is basically a part of the major corporate law reform program undertaken by the federal government under which the CLERPA'99 was enacted. Incidentally the CLERPA'04 came into existence after the incidents of some spectacular publicly traded corporate failures. Therefore it primarily addresses the issues of disclosures by companies listed on the stock exchanges. It significantly reformed the corporate fund-raising regime and the CLERPA'04 does not explicitly amend any provisions of the Corporations Act 2001 (CA'01) governing prospectus criminal liabilities. Based on both the expert opinions consulted and the explanations given above, it is assumed in this study that the CLERPA'04 does not affect the subject matter of this article and therefore no post-Enron reforms in Australia are relevant to this discussion. However, such inaction will be discussed in this study in reference to the other two jurisdictions.

Compared to the U.S. and Australian reforms, the post-Enron reforms in Canada are very clear regarding their applicability to prospectus liabilities. The U.S. corporate scandals impacted Canada. Following the path of the U.S. government, the Ontario government tabled Bill 198 for reforms aimed at regaining investor confidence shattered by the U.S. corporate disasters coupled with some domestic incidents. ${ }^{81}$ The Bill was known as An Act to

\footnotetext{
securities market. Some of the provisions of this Act will be discussed later in this paper.

79. James MCCON ViLL, An INTROduction to CLERP 9 (2004).

80. Id.

81. Emerson \& Clarke, supra note 3.
} 
implement Budget measures and other initiatives of the Government. The short title of the Act is Keeping the Promise for a Strong Economy Act (Budget Measures) 2002 (BMA'02). It amended various provisions of the Ontario Securities Act 1990, R S O (OSA'90). Some of the most important of those reforms are mentioned below. As regards criminal offences concerning securities, the BMA'02 makes significant reforms by adding sections 126.1 and 126.2 to the OSA'90, imposing prohibitions on fraudulent and deceptive conduct in offering securities by individuals or corporations. ${ }^{82}$ The BMA'02 also enhanced penalties for offences regarding prospectus disclosures. These are discussed below.

\section{Legal Provisions Concerning Prospectus Criminal Liabilities}

In the aftermath of the stock market debacle in October 1929 in the U.S., the Securities Act 1933 (SA'33) introduced securities regulation at federal level alongside the preexisting state regulation. The SA'33 incorporated the disclosure philosophy for the first time in the United States. As expounded by the U.S. Supreme Court, the fundamental purpose of the federal securities laws is "to substitute a philosophy of full disclosure for the philosophy of caveat emptor." ${ }^{83}$ Previously the U.S. securities markets had been regulated by respective state regulatory bodies alone, in pursuance of the paternalistic merit philosophy. The Congress passed the SA'33 "to protect investors during the initial offering of a security." ${ }^{\prime 84}$ One of the prime purposes of the SA'33 is "to provide the investor with enough information to make a sound economic decision in purchasing a security."

Under section 6 of the SA'33, a company willing to go public is required to register its registration statement or prospectus with the Securities and Exchange Commission (US-SEC). Section 10 of this Act prescribes the information to be included in a prospectus. The prescribed contents include all material information regarding the nature of the securities, issue and issuer necessary for making educated investment decisions. It follows a "general disclosure test." Sections 17 and 24 make fraudulent and deceptive disclosures an offence. The SA'33 ascribes both civil and criminal liabilities

82. Keeping the Promise for a Strong Economy Act (Budget Measures), S.O. § 182 (2002) (Can.).

83. Steven Thel, Section 12(2) of the Securities Act: Does Old Legislation Matter?, 63 FordHam L. REV. 1183 at 1183 (1995).

84. Kyle M. Globerman, The Elusive and Changing Definition of a Security: One Test Fits All, 51 FLA. L. REv. 271, 279 (1999).

85. $I d$. 
for a defective prospectus. ${ }^{86}$ Regarding criminal liabilities for defective prospectuses, section 24 of the SA'33, as quoted in the next section, imposes liability on any person who willfully violates prospectus requirements set out in this Act or in any bylaws promulgated thereunder.

Although this section does not categorically identify the persons who are liable for committing an offence, numerous judicial interpretations of this section have vividly specified that all members of a coalition of the prospectus are criminally liable for defective disclosure in a registration statement. The coverage of the above expression "any person" is discussed below, which will demonstrate that auditors and lawyers could be caught under criminal liability entrenched in the SA'33. In addition, they (auditors and lawyers) can be sued as principal violators under the $\mathrm{SOX}^{\prime} 02 .^{87}$

In Australia, disclosure requirements in prospectuses are governed under Chapter 6D of the CA'01. Under this Chapter, section 728(1) provides that a person must not offer securities to the public under a prospectus ${ }^{88}$ which includes misleading or deceptive statements or omits material information required by $710,711,712,713,714$ or 715 of this Act from the prospectus. ${ }^{89}$ These sections set out some general and specific disclosure tests. For example, section 710 provides that a prospectus must contain all the material information that would be reasonably required to make informed judgment of the offer by the investors or their professional advisors. The onus is on the issuer to determine whatever information they believe would be useful for investors or their financial advisors to make educated investment decisions. In addition to this so-called "general disclosure test," the CA also requires the issuer to disclose categorically rights and liabilities attached to the underlying securities, and the operational records and financial health of the issuer. Section 711 is concerned with the terms and conditions of the offer, the formation and promotion of the issuer, and interest and fees paid to the persons involved in the making of the offer. Sections 714 and 715 deal with the disclosure of risks associated with the offer, the nature of the issuer's business and the use of funds to be raised through the prospectus. Therefore,

86. See Securities Act of 1933, §§ 11-12 (1933) (describes civil liabilities for defective prospectus).

87. Backer, supra note 70 , at 985 .

88. Section 728(1) does not actually use the term "prospectus." Instead it uses "disclosure documents" which include: "Prospectuses, short-form prospectuses, profile statements and offer information statements." Corporations Act, 2001, c. 6D, § 709 (2005) (Austl.). "Prospectus" is a common term used widely in respect of raising funds by corporations. The term "prospectus" has been used in this study to denote all sorts of disclosure documents issued by corporations for the purposes of initial public offerings.

89. Corporations Act, 2001, c. 6D, § 728(1) (Austl.). 
a cursory construal of the requirements of disclosure in prospectuses shows that the issuers are obligated to disclose certain information to a reasonable extent in addition to general disclosure requirements. It would be a contravention of these requirements for the prospectus to contain misleading or deceptive statements and omit from the prospectus a fact which was required to have been included.

Both civil and criminal liabilities apply to the contravention of section 728(1). ${ }^{90}$ Ascribing criminal liability for the contravention of section 728(1), section 728(3) provides that it will be an offence if the misleading or deceptive statement or omission or new circumstance is "materially adverse from the point of view of an investor." breach of this section, it has been stated that "criminal liability is imposed where the result of a contravention of section 728(1) was that 'bad news' was withheld from investors." ${ }^{.92}$

The above discussion shows the criminal liability applies to the violation of prospectus requirements; persons liable for such violation are discussed below. It may be noted here that post-Enron legal reforms in Australia did not affect these provisions.

Canadian securities laws, like those in the USA and Australia, require companies willing to go public to obtain regulatory approval for issuing prospectuses to the public. There are both long and short forms of prospectuses. Generally a prospectus under Ontario securities law should contain all material information regarding "the company, business, management, finances, existing securities, and the securities being qualified." ${ }^{\prime 93}$ The prospectus should be drafted in such a simple manner that investors generally can read it. ${ }^{94}$ The responsibility of the securities regulator is to ensure that prospectuses embody "full, true, and plain disclosure of material facts relating to the securities issued or proposed to be distributed and shall comply with the requirements of Ontario securities law." ${ }^{95}$

90. See id. § 729 (imposing civil liabilities for violations of $\S 728$ ).

91. Id. $\S 728(3)$ ("A person commits an offence if they contravene subsection (1) and: (a) the misleading or deceptive statement; or (b) the omission or new circumstance; is materially adverse from the point of view of an investor.").

92. Robert Baxt, Ashley J. Black \& Pamela F. Hanrahan, Securities and Financial SERVICES LAW 154 (6th ed. 2003).

93. David Johnston \& Kathleen Rockwell, Canadian Securities Regulation 83 (3d ed. 2003).

94. Report of the Attorney-General's Committee on Securities Legislation in Ontario para. 5.09 (Toronto: Queen's Printer, 1965).

95. Ontario Securities Act, R.S.O., c. S.5 § 56(1) (1990) (Can.). 
The OSA' 90 makes certain disclosure or non-disclosure of material facts a punishable offence. Offences have been split into three types: general offences, offences by directors and/or officers; and offences relating to insider trading. General offences are contained in section 122(1) of the OSA'90. ${ }^{96}$ It is a general offence under section 122(1)(a) to submit to the Ontario Securities Commission (OSC) or its (OSC's) representatives statements that are misleading, untrue or omits to include material facts. Section 122(1)(b) provides that the inclusion of any statement made in any required documents including prospectuses that is misleading or untrue or contains omission in respect of a material fact is an offence. Section 122(1)(c) is wider than the preceding two sections. According to section 122(1)(c), any contraventions of securities laws of Ontario are punishable offences. The expression "misleading, untrue or contains omissions" as embodied in sections 122(1)(a) $\&$ (b) encapsulates the statutory definition of "misrepresentation" contained in section 1(1) of the OSA'90. Given the wider scope of section 122(1)(c), it has been argued that any offensive violation of Ontario securities legislation can be prosecuted under this penal provision. ${ }^{97}$

In addition to the above provisions, the post-Enron amendment inserted sections 126.1 and 126.2 as alluded to earlier. Section 126.1 is concerned with fraud and market manipulation. It provides that:

96. See id. § 122(1). Offences, general: § 122

(1) Every person or company that,

(a) makes a statement in any material, evidence or information submitted to the Commission, a Director, any person acting under the authority of the Commission or the Executive Director or any person appointed to make an investigation or examination under this Act that, in a material respect and at the time and in the light of the circumstances under which it is made, is misleading or untrue or does not state a fact that is required to be stated or that is necessary to make the statement not misleading;

(b) makes a statement in any application, release, report, preliminary prospectus, prospectus, return, financial statement, information circular, take-over bid circular, issuer bid circular or other document required to be filed or furnished under Ontario securities law that, in a material respect and at the time and in the light of the circumstances under which it is made, is misleading or untrue or does not state a fact that is required to be stated or that is necessary to make the statement not misleading; or

(c) contravenes Ontario securities law, is guilty of an offence and on conviction is liable to a fine of not more than $\$ 5$ million or to imprisonment for a term of not more than five years less a day, or to both. 1994 , c. 11 , s. $373 ; 2002$, c. 22 , s. 181 (1).

Exemption

(1.1) Clauses (1)(a) and (b) do not apply to a statement made or given to the Commission in a submission in respect of a proposed rule or policy.

97. Johnston, supra note 94, at 271. 
A person or company shall not, directly or indirectly, engage or participate in any act, practice or course of conduct relating to securities or derivatives of securities that the person or company knows or reasonably ought to know, (a) results in or contributes to a misleading appearance of trading activity in, or an artificial price for, security or derivative of a security; or (b) perpetrates a fraud on any person or company.

Section 126.2 prohibits persons and companies from making a misleading or untrue statement in relation to securities. It reads that:

A person or company shall not make a statement that the person or company knows or reasonably ought to know, (a) in a material respect and at the time and in the light of circumstances under which it is made, is misleading or untrue or does not state a fact that is required to be stated or that is necessary to make the statement not misleading; and (b) significantly affects, or would reasonably be expected to have a significant effect on, the market price or value of a security.

Under the above two new sections, it is a criminal offence to issue a defective prospectus for raising funds from the public for firms.

It is apparent from the preceding discussions of the legal provisions of the United States, Australia and Canada that disclosure requirements of prospectuses are wide and the onus is on the issuer to determine the content and extent of information to be included in a prospectus. However, Australia prescribes some specific information to be disclosed. All these jurisdictions impose criminal liability for defective prospectuses but none of the three categorically identifies the persons who are criminally liable for such a prospectus. It must be noted that neither the U.S. nor Australia has amended the relevant provisions discussed above following the Enron effects on their domestic markets, but Ontario has added new sections by defining fraudulent conduct with regard to corporate disclosure that may trigger criminal liabilities for defective prospectuses.

\section{Criminal Liability of Auditors and Lawyers for Defective Prospectuses under Securities Laws}

Statutory provisions are not clear in the U.S. whether an accountant or attorney should be held criminally liable for a defective prospectus. Criminal liabilities for defective prospectuses have been imposed under section 24 of the SA'33. This section reads that:

Any person who willfully violates any of the provisions of this title [SA'33], or the rules and regulations promulgated by the Commission under the authority thereof, or any person who willfully, in a registration statement filed under this title, makes any untrue statement of a material fact or omits to state any material fact required to be stated therein 
or necessary to make the statements therein not misleading, shall upon conviction be fined ... or imprisoned. . . .

Section 17 of the SA'33 proscribes fraudulent interstate transactions in securities that include "offer or sale of any securities." Such conduct is "unlawful for any person" that may be involved in these transactions. But it does not clearly impose liability on particular persons.

Provisions regarding lodgment of prospectus with the SEC are clear. Unless exempted, companies willing to go public are required to lodge a registration statement ${ }^{98}$ and prospectus ${ }^{99}$ with the SEC for floatation; the contents of these documents are prescribed in sections 7 and 10 respectively. Sections 11 and 12 provide for civil liabilities for defective registration statements and prospectuses. Every person including directors, underwriters, auditors and lawyers may be liable for defective prospectuses under section $11 .{ }^{100}$

With regard to the importance of the role of accountants and lawyers, statutory provisions have been judicially interpreted in favour of accountants' criminal liability alongside the existence of civil liability. In State v. Tarzian the Court of Appeal of Arizona affirmed the criminal conviction of the accountant for auditing the accounts of the company which lodged misleading information with the securities regulator. ${ }^{101}$ In applying criminal liability provisions, the U.S. Court of Appeals for the Second Circuit highlighted the need for investigation by accountants before providing a certificate of fairness and rejected the plea of ignorance. The court observed that the certificates of accountants in relation to corporate disclosures "can be instruments for inflicting pecuniary loss" on investors. ${ }^{102}$

Further, it is generally argued that the profession of auditors plays a crucial role in presenting a distorted financial position of the issuer. ${ }^{103}$ Similar to the position of accountants, lawyers have been held primarily liable by several courts for a defective prospectus. ${ }^{104}$ Therefore, both auditors and

98. Coffee \& Seligman, supra note 75, at 77 (stating "A registration statement "means a filing that includes the prospectus and other information required by section 7 of the Securities Act.").

99. Id. "A prospectus is defined as 'an offering document that includes the information required by section 10 (a) of the Securities Act."”

100. Securities Act of $1933 \S 11,15$ U.S.C. $\S 77(j)$ (2004).

101. 665 P.2d 582 (Ariz. Ct. App. 1983).

102. United States v. Benjamin, 328 F.2d 854, 863 (2d Cir. 1964).

103. Markovic, supra note 27.

104. See SEC v. Seaboard Corp, 677 F.2d 1301 (9th Cir. 1982); Bradford White Corp v. Ernst \& Whinney, 872 F.2d 1153 (3d Cir. 1989); Adam v. Silicon Valley Bancshares, 884 F. Supp. 1398 (N.D. Cal. 1995). 
attorneys in the U.S. are held criminally liable for defective prospectuses although statutory provisions do not categorically name them. Their involvement in the preparation of prospectuses attracts this liability.

In Australia, as discussed previously, auditors are now civilly liable for economic loss or damages suffered by investors in reliance on the audit report included in a prospectus. In addition to the liability under the tort of negligence, auditors and attorneys are also liable to investors for defective prospectuses under section 729 and possibly section 1041, where they are found responsible for the incorporation of false and misleading statement in the prospectus. ${ }^{105}$ Recently some statutory changes have been made to professionals' civil liability in Australia. The CLERPA'04 introduced proportionate liability provisions by amending the relevant legislation. ${ }^{106}$ According to these amendments, an auditor or lawyer can be held liable only for that portion of damages, arising from misleading and deceptive conduct, which is judged to have been caused by the defendant's conduct. ${ }^{107}$ This provision applies to all defendants including auditors and lawyers who concurrently commit a wrong that gives rise to economic loss or damage to property. All of these liability provisions deal with civil liability: they do not apply to fraudulent or deceptive conduct that may attract criminal liability. ${ }^{108}$ Nonetheless it is important to note here that the persons who are civilly liable for defective prospectuses may arguably be criminally liable if the misleading or deceptive statement or omission is materially adverse from the point of view of an investor as described in section 728(3) of the CA'01. It must be mentioned that while section 728(3) of the CA'01 makes raising funds by a company by issuing a prospectus containing misleading and deceptive statement which is "materially adverse" to investors a serious offence, ${ }^{109}$ the question of professionals' liability remains unclear.

According to section 700(3) of the CA'01, the issuing company is clearly liable. But in the absence of judicial interpretation of this section, it is quite uncertain whether this liability is limited to the issuer only, or extended to others involved in the preparation of a prospectus. ${ }^{110}$ Arguably, it may apply

105. H.A.J. Ford ET AL., Ford's PrinCIPLES OF CORPORATIONS LAW 604 (12th ed. 2005).

106. Corporations Act, $2001 \S 1041 \mathrm{I}$ (Austl.); Australian Securities and Investment Commission Act, 2001, § 12GF (Austl.); Trade Practices Act, 1974, § 52 (Austl.).

107. See ForD ET AL., supra note 105, at 610.

108. $I d$.

109. Michael A. Adams, Essential Corporate Law 74 ( $2 \mathrm{~d}$ ed. 2005) (penalties for this offense may be up to 200 penalty units $(\$ 22,000)$ and/or imprisonment of a period which may extend up to five years, which will be discussed later in this article).

110. BAXT ET AL., supra note 92. 
to the individuals by operation of section 52 of the CA' 01 which explains the meaning of doing an act by saying that "[a] reference to doing an act or thing includes a reference to causing or authorising the act or thing to be done." Referring to this section, it has been argued that "a person who caused or authorised the offer is also treated as having made it and can therefore contravene section 728(1)."111

Section 729 of the CA2001 categorically imposes civil liability for defective prospectuses on the issuer, present and proposed directors, underwriters, a person named in the prospectus with their consent as having made a statement included in the disclosure, and "a person who contravenes, or is involved in the contravention of, subsection 728(1)" of the CA'01. Arguably, a plain and simple interpretation of this section may imply that all members of an IPO coalition are civilly liable under this section and that this was the intention of the government in inserting Chapter $6 \mathrm{D}$ in the CA'01 by the CLERP Act 1999. ${ }^{12}$ But some writers observe that this section does not apply to criminal liability. ${ }^{113}$

In addition to section 728 of the CA'01, sections $1041 \mathrm{E}-1041 \mathrm{G}$ of this Act also prohibits misleading, deceptive or dishonest conduct in relation to dealing with financial products. These provisions complement section 728 in imposing prohibition on the issuance of defective disclosure for raising corporate funds. Section $1041 \mathrm{E}^{114}$ clearly says that "it is an offence to

111. $I d$.

112. The Treasury, Australian Gov't, Corporate Disclosure: Strengthening the FinANCIAL REPORTING FRAMEWORK 160 (2002), available at $\mathrm{http}$ ://www.treasury.gov.au/contentitem.asp ?NavId $=\&$ ContentID $=403$.

113. BAXT ET AL., supra note 92, at 154-55.

114. Section 1041E: False or misleading statements

(1) A person must not (whether in this jurisdiction or elsewhere) make a statement, or disseminate information, if:

(a) the statement or information is false in a material particular or is materially misleading; and

(b) the statement or information is likely:

(i) to induce persons in this jurisdiction to apply for financial products; or

(ii) to induce persons in this jurisdiction to dispose of or acquire financial products; or (iii) to have the effect of increasing, reducing, maintaining or stabilising the price for trading in financial products on a financial market operated in this jurisdiction; and

(c) when the person makes the statement, or disseminates the information:

(i) the person does not care whether the statement or information is true or false; or

(ii) the person knows, or ought reasonably to have known, that the statement or information is false in a material particular or is materially misleading.

Note 1: Failure to comply with this subsection is an offence (see subsection 1311(1)). For defences to a prosecution based on this subsection, see Division 4.

Note 2: Failure to comply with this subsection may also lead to civil liability under section $1041 \mathrm{I}$.

For relief from liability under that section, see Division 4. 
knowingly, recklessly, or negligently make a false or misleading statement or disseminate such information where it is likely, inter alia, to induce a person to acquire financial products." ${ }^{115}$ Unlike section 728, section $1041 \mathrm{E}(3)$ imposes strict liability on the offenders. Inducement to deal in a financial product by misleading, false or deceptive conduct made knowingly, or recklessly is prohibited under section 1041F. Section $1041 \mathrm{G}$ proscribes dishonest conduct of financial service providers in relation to financial product. All these sections prohibit "a person" from violating the above prohibitions. Section 1041E prohibits a person from "making" false or misleading statement; section $1041 \mathrm{~F}$ provides that "a person" must not "induce" another person to deal with securities, and section $1041 \mathrm{G}$ forbids "a person" to "engage" in dishonest conduct in relation to financial products. The meanings of these three terms, make, induce and engage, are not provided in the CA'01 and are therefore open for judicial interpretations. Arguably, an auditor and attorney may be held criminally liable under the above sections. However, absent some judicial interpretations by competent courts, Australian securities law seems unclear as to whether auditors and lawyers are criminally liable for a defective prospectus. ${ }^{116}$

Like the abovementioned Australian and U.S. law, Canadian law does not specifically name anyone who should be held liable for an offence under this section. Instead sections 122(1), 126.1 and 126.2 of the OSA'90 impose liability on every person or company that makes a defective statement included in a prospectus and submitted to securities commission or issued to the public. It seems very wide but is still vague in respect of the identify of persons to be held liable. This is so because it does not explain who is considered to have "made" the prospectus. As mentioned previously, a prospectus is typically prepared jointly by promoters, directors, auditors, lawyers, issue managers and underwriters. Hence a simple interpretation of the expression "every person or company" or "a person or company" may imply that either all of these individuals or the issuer per se is liable for an

(2) For the purposes of the application of the Criminal Code in relation to an offence based on subsection (1), paragraph (1)(a) is a physical element, the fault element for which is as specified in paragraph (1)(c).

(3) For the purposes of an offence based on subsection (1), strict liability applies to subparagraphs (1)(b)(i), (ii) and (iii)

Note: For strict liability, see section 6.1 of the Criminal Code.

115. Julie A. Cassidy, Corporations Law: Text and Essential Cases 163 (2005).

116. However, an auditor as an accomplice can be held liable for a defective prospectus under $\S 5$ of the Crimes Act, 1914 (Austl.). BAXT ET AL., supra note 92, at 155. 
offence under this section. Ontario law puts more emphasis on the individuals whilst U.S. and Australian law place blame on the issuer first.

\section{Defences Available to Auditors}

The U.S. legislation provides a wide scope of defence to this liability that requires the plaintiff to prove both mens rea or scienter and actus reus. A person can be held liable under section 24 of the SA'33 only if the wrongful act or omission is done willfully as clearly articulated in the text of the section. ${ }^{117}$ It may not be very difficult to prove actus reus, but proving willfulness may be hard. However, as regards civil action, it was held by the U.S. Supreme Court in Aaron v. SEC that scienter is not a necessary element to be established for a successful suit under section 17 of the SA'33. ${ }^{118}$ Nonetheless, it is unclear whether scienter is an essential element for a criminal case under section 17 of the SA'33.

A number of defences are available to both civil and criminal liability for flouting prospectus requirements in Australia. ${ }^{119}$ These defences are contained in sections 731 to 733 of the CA'01. A defendant will be acquitted from criminal liability under section 728(3) if a single defence can be established. However, defences available vary between defendants "depending on the type of disclosure document, the nature of defect and the identity of the person" trying to rely on the defence. These defences applicable to prospectuses are: reasonable inquiries about the facts in question, reasonable reliance on expert opinions or on documents, withdrawal of consent to be named in the prospectus, and lack of factual awareness.

Defying the common law provisions espoused in the landmark judgment of the House of Lords in Derry v. Peek, a legislative reform introduced under the Directors Liability Act 1890 (UK) allowed subscribers to sue directors of an issuer of prospectus without proving the knowing or reckless disclosure of misleading or defective statements in a prospectus. However a statutory defence was made available that the defendant had reasonable grounds to believe the truth of the impugned prospectus statement. This provision basically imposed a "burden of disproof" on defendants that the inclusion of the misleading or defective statement did not result from their deliberate or reckless conduct. Borrowing from that legislative spirit, all of the defences

117. $\S 24$ of the Securities Act of 1933,15 U.S.C.A. $\S 77 x$ (West 2007).

118. 446 U.S. 680, 695-97 (1980).

119. BAXT ET AL., supra note 92, at 155. 
incorporated in the $\mathrm{CA}^{\prime} 01$ entitle the defendants to disprove the claim of guilty leveled against them by subscribers, and subscribers are no longer required to prove the guilt of the defendant.

\section{Reasonable Inquiries Defence: Section 731}

This defence requires the defendant to properly inquire about the fact of the statement and based on this inquiry the defendant should make a reasonable decision that the statement is not misleading or deceptive. If the allegation is about omission of material fact from the prospectus, the defendant must make sure that his/her inquiries did not find any omission as alleged subsequently. The successful arguments for this defence will enable the defendant to escape liability. This defence applies to all persons who are potentially liable for a breach of section 728(1) of the CA' 01 .

There is no single definition of "reasonable inquiry." The reasonability of inquiry will be determined on a case-by-case basis depending on the circumstances surrounding a particular offer. In this regard courts "would have regard to established best practice in the preparation and verification of prospectuses." "20 That is, persons of each category such as directors, professionals, underwriters and issue managers will have to play their due role by employing their best effort in order to know the truth before including a statement in a prospectus. Failure to carry out this query may attract criminal liability.

This defence broadly resembles the defence of due diligence, which was a statutory defence in Australia until 2000. Although a true due diligence defence no longer exists in the CA'01 following the commencement of the CLERPA'99 from March 2000, the requirements embodied in the amended 
section $731^{121}$ exercising due diligence appear to be still relevant and helpful in establishing the reasonable inquiry defence. ${ }^{122}$

\section{Reasonable Reliance Defence-Section 733(1)}

This defence provides that a person is neither civilly nor criminally liable for the contravention of section 728(1) if the defendant can prove that he/she reasonably relied on information provided by another person. However, there are some qualifications with regard to that other person. According to this section, defendants are required to prove that they "placed reasonable reliance on information given to them: (a) if the person is a body, by someone other than a director, employee or agent of the body; or (b) if the person is an individual, by someone other than an employee or agent of the individual." ${ }^{123}$

Section 733(3) contains some exclusion provisions unfavourable to professionals including auditors and lawyers. According to these provisions, persons providing professional or advisory services to a defendant under section 728 are not an agent of the recipient of the service merely through acting in that capacity. Therefore an auditor or lawyer working for a

121. Section 731 Due diligence defence for prospectuses

Reasonable inquiries and reasonable belief-statements

(1) A person does not commit an offence against subsection 728(3), and is not liable under section

729 for a contravention of subsection 728(1), because of a misleading or deceptive statement in a prospectus if the person proves that they:

(a) made all inquiries (if any) that were reasonable in the circumstances; and

(b) after doing so, believed on reasonable grounds that the statement was not misleading or deceptive.

Reasonable inquiries and reasonable belief-omissions

(2) A person does not commit an offence against subsection 728(3), and is not liable under section 729 for a contravention of subsection 728(1), because of an omission from a prospectus in relation to a particular matter if the person proves that they:

(a) made all inquiries (if any) that were reasonable in the circumstances; and

(b) after doing so, believed on reasonable grounds that there was no omission from the prospectus in relation to that matter.

122. For further details, see BAXT ET AL., supra note 92, at 158.

123. Corporations Act, 2001, § 733(1) (Austl.):

(1) A person does not commit an offence against subsection 728(3), and is not liable under section 729 for a contravention again st subsection $728(1)$, because of a misleading or deceptive statement in, or an omission from, a disclosure document if the person proves that they placed reasonable reliance on information given to them by:

(a) if the person is a body-someone other than a director, employee or agent of the body; or

(b) if the person is an individual-someone other than an employee or agent of the individual. (2) For the purposes of subsection (1), a person is not the agent of a body or individual merely because they perform a particular professional or advisory function for the body or individual. 
corporation in the preparation of a prospectus cannot bind the corporation for his/her faults. Professionals themselves shall be liable for their fault committed in providing in their service. Therefore, professionals must be diligent and careful in examining the relevant documents depending on the relevant circumstances.

This is indeed a good defence for the issuer, directors, and promoters. However, a blind reliance is not an acceptable defence. Reliance on the opinion of another person must be reasonable. Before putting reliance on the information provided by a third party, the defendant must be concerned about the capability and expertise of the professional or advisor concerned. One cannot knowingly rely on the information provided by a person who is not generally involved in providing that sort of service. That is, financial advice must be obtained from a qualified accountant, not from a highly reputed lawyer. In this respect, the term "reasonable" entails that the defendant seeking this defence to rely on "should have acted reasonably in regard to circumstances which it knew or ought to have known." 124 Otherwise, the defence should be unavailable.

\section{Withdrawal of Consent Defence: Section 733(3)}

Any person involved in the preparation of a prospectus and whose name would be included in it, may decide to withdraw his/her name from the prospectus before its publication, on the ground that the prospectus contains some misleading or defective statement or omits to state some material facts in it. The persons who are entitled to take advantage of this defence are: directors, promoters, underwriters and professionals including auditors and lawyers.

Section $733(3)^{125}$ does not clearly state when and how the withdrawal should be effected. However, it is assumed from its predecessor,

124. BAXT ET AL., supra note 92 , at 159.

125. Corporations Act, 2001, § 773(3) (Austl.):

Withdrawal of consent-statements and omissions

A person who is named in a disclosure document as:

(a) being a proposed director or underwriter; or

(b) making a statement included in the document; or

(c) making a statement on the basis of which a statement is included in the document; does not commit an offence against subsection 728(3), and is not liable under section 729 for a contravention against subsection 728(1), because of a misleading or deceptive statement in, or an omission from, a disclosure document if the person proves that they publicly withdrew their consent to being named in the document in that way. 
section 1009(3) of the Corporations Law, that on becoming aware of the defects of the prospectus the withdrawal with reasons should be made public any time before the allotment of securities under the prospectus. ${ }^{126}$ Both the time and way of withdrawal are significant to investors because the potential subscribers must be reasonably informed of such withdrawals. From this point of view, the absence of this clarity appears to be a loophole which needs to be made clear immediately. This shortcoming may lead to acquittal of true offenders in criminal cases.

Similar to the available defence in the U.S., the above discussions show that the scienter element is required to be proved for a successful prosecution in Australia as well. It is a difficult task to prove and therefore the defendants have ample scope to escape criminal liability for defective prospectuses.

Similar to the other two jurisdictions, a wide range of defences are available to the offence committed under section 122(1) of the OSA'90 in Canada. Section 122(2) makes the same defences available to both individuals and issuers. These defences are: ignorance and "the exercise of reasonable diligence." This section provides that neither the individuals nor the issuer will be held liable for a defective prospectus where 'the person or company did not know and in the exercise of reasonable diligence could not have known' the defect of the prospectus. Ignorance includes both: ignorance of the defect in the disclosure and ignorance of the circumstances which require that a prospectus be free from misleading statements. ${ }^{127}$

These defences are wider than those available in the U.S. and Australia. This is so because ignorance of the circumstances under which a prospectus should be free from misleading statements may also be a defence. Such a wide scope of defence virtually weakens the liability regime.

It can be inferred from the above discussion that offenders may escape criminal liability in all of the three jurisdictions taking advantage of explicit defences and/or ambiguities present in the liability provisions.

126. BAXT ET AL., supra note 92 , at 160 .

127. Ontario Securities Act, R.S.O., 1990, c. S.5, § 122(2): Defence-Without limiting the availability of other defences, no person or company is guilty of an offence under clause (1)(a) or (b) if the person or company did not know and in the exercise of reasonable diligence could not have known that the statement was misleading or untrue or that it omitted to state a fact that was required to be stated or that was necessary to make the statement not misleading in light of the circumstances in which it was made. 


\section{Penal Sanctions for Offences Related to Disclosures in Prospectuses}

Section 24 of the SA'33 in the U.S. limits the amount of fine up to U.S. $\$ 10,000$ that can be imposed on a defendant upon conviction. A defendant can be either fined or imprisoned for a period of not more than five years, or can be punished with both on conviction under section 24 of the SA'33. ${ }^{128}$ It does not distinguish between individuals and issuers in respect of penalties.

The post-Enron reform, the SOX'02, has considerably enhanced the penalties for the violation of securities fraud provisions under the SEA'34 which primarily applies to the secondary market. As mentioned earlier, the SOX'02 may also apply to the IPO market as well. In that case, the maximum fine and imprisonment are U.S. \$5 million and 20 years respectively where the offender is a natural person. ${ }^{129}$ In the case of a person other than a natural person, the maximum fine has been increased from U.S. \$2.5 million to U.S. $\$ 25$ million. ${ }^{130}$ However its applicability to prospectuses is doubtful, as it does not amend the prospectus-related legal provisions.

The term of maximum imprisonment is the same, five years, in the U.S. and Australia. ${ }^{131}$ But a big difference is evident if the SOX'02 applies to the IPO market, because the term of imprisonment has been increased up to 20 years. The pecuniary penalties are also different. According to schedule 3 of the CA'01, the sanction applicable to individuals for committing an offence section 728(3) is either 200 penalty units or imprisonment for a period of five years or both. As explained in section 4AA of the Crimes Act 1914 (Cth), a penalty unit is equivalent to AU $\$ 110$. Therefore the amount of pecuniary penalty awardable against an auditor would be AU $\$ 22,000$ (US $\$ 16,500$ approx) for the contravention of prospectus requirements set forth in section 728 of the CA'01, which is considerably different from the U.S. equivalent mentioned above.

Similar sanctions apply to the violation of sections $1041 \mathrm{E}-1041 \mathrm{G}$ of the $\mathrm{CA}^{\prime} 01$ as stated in schedule 3 of the $\mathrm{CA}^{\prime} 01$. These three sections generally prohibit any false or misleading statements or dishonest concealment of material facts in relation to financial products under the CA'01. Therefore, this penal section may also apply to disclosure in prospectuses. However, it

128. 18 U.S.C. $\S 3623$ (1984).

129. Guy P. Lander, What Is Sarbanes-Oxley? 102 (2003). Previously the maximum fine was U.S. $\$ 1$ million and imprisonment for a term of 10 years.

130. Id.

131. Australian penal provision is cited below. 
does not make a significant difference in that the sanctions are identical to those prescribed under section 728(3). Individuals and corporations have been treated equally, unlike the SOX'02.

Section 122(1) of the OSA'90 in Canada provides for sanctions against both individuals and corporations equally. An individual or the issuer can be punished on conviction for an offence under this section with "a fine of not more than CA $\$ 5$ million (US $\$ 4.3$ million) or to imprisonment for a term of not more than five years less a day, or to both." This penalty is applicable to the offenders who "make" a defective statement embraced in a prospectus. Previously, the maximum fine was CA $\$ 1$ million and the term of imprisonment was two years. These sanctions were enhanced in 2002 in the aftermath of Enron. ${ }^{132}$

Alongside section 122(1), section 122(3) deals only with directors and officers "who authorizes, permits or acquiesces in the commission of an offence under subsection (1) [§ 122(1)] by the company or person, whether or not a charge has been laid or a finding of guilt has been made against the company or person in respect of the offence under subsection (1)..." Such an authorisation, permission or acquiescence in the commission of an offence has been made punishable with the same sanctions applicable to the "making" of the aforementioned defective statement. ${ }^{133}$

It should be noted that these two sections, section 122(1) and section 122(3), are different in respect of both the persons liable for the offence and the nature of offences. Section 122(1) deals with committing the offence, whereas section 122(3) concerns authorisation, permission or acquiescence in the commission of an offence. Both subsections are relevant to the role of auditors and lawyers, because they may be subject to both primary and secondary liabilities in Canada depending on the role they played in a given prospectus, as discussed earlier.

It is interesting to notice that all three jurisdictions provide for a maximum term of five years imprisonment for prospectus offences, except for SOX'02 provisions. Both in the U.S. and Australia, the five-year term was in

132. 20 S.O. § 122 (1994), amended by Keeping the Promise for a Strong Economy Act, 22 S.O. $\S 181(2002)$ (Ont.).

133. 20 R.S.O. § 122(3) (1990) (Ont.):

Every director or officer of a company or of a person other than an individual who authorizes, permits or acquiesces in the commission of an offence under subsection (1) by the company or person, whether or not a charge has been laid or a finding of guilt has been made against the company or person in respect of the offence under subsection (1), is guilty of an offence and is liable on conviction to a fine of not more than $\$ 5$ million or to imprisonment for a term of not more than five years less a day, or to both. 
place before the Enron effects, but Canada increased this term from two years to five years in response to Enron and some domestic incidents. Canada has also increased pecuniary penalties from CA $\$ 1$ million to CA $\$ 5$ million (US $\$ 4.3$ million), where Australia trails some distance behind with its lower pecuniary penalties.

\section{Conclusions}

After recent mega-scandals of corporate bankruptcy, public confidence in the quality of services provided by auditors has been dazed and quick legislative measures have been taken to prevent corporate malpractices. ${ }^{134}$ The auditors' role is perhaps the most important of many roles played by accounting professionals and thereby they work as a gatekeeper in line with other professionals such as securities lawyers and merchant bankers. ${ }^{135}$ However, the role of lawyers is also very important because primary functions of securities lawyers are to assist the underwriters in exercising due diligence in the preparation of a prospectus and to ascertain that the prospectus complies with all the legal requirements. ${ }^{136}$ As members of the coalition, underwriters, attorneys and accountants jointly provide credible assurance to investors that prospectus disclosures are accurate. ${ }^{137}$ It is thus reasonably argued that "the current post-Enron atmosphere demands more from capital market gatekeepers." 138

The foregoing investigation of the prospectus liability regimes in the U.S., Australia and Canada reveals some similarities and differences amongst these jurisdictions with regard to the offensive conduct, persons liable for that conduct, defences available to that liability and penalties enforceable upon conviction. A great similarity persists in relation to the identification of persons who should be held liable. All three jurisdictions seem to impose liability on any person who is involved in the issuance of securities, although different terms have been used. Expressions of law regarding the identity of persons who are potentially liable for defective prospectuses are ambiguous. Such an ambiguity is favorable to offenders who are entitled to take advantage of the "benefit of doubt," a fundamental principle of the administration of

134. Birke, supra note 13 , at 891.

135. Id. at 895 .

136. Candida P. Jose, Section 11 of the Securities Act of 1933: The Disproportionate Liability Imputed to Accountants, 27 DEL. J. CORP. L. 565, 584 (2002).

137. Stephen Choi, Market Lessons for Gatekeepers, 98 Nw. U. L. REV. 916, 962 (1998).

138. Birke, supra note 13 , at 898 . 
criminal justice utilised all over the world. This is so because the legislation does not provide any meaning of "making" the offer or "offering" of securities or "engaging" in such activities. Therefore, it is uncertain that an auditor or lawyer must fall within the purview of such expressions. However, some U.S. cases have been cited in which professionals like auditors and lawyers were held liable for defective prospectuses. Clarity of the purpose and purview of the law is essential for its effective enforcement. The operation of capital markets is a complex combination of the roles of several professions. Legal certainty in respect of all aspects of this market is necessary for its smooth functioning. ${ }^{139}$ It has been argued that for the protection of investors ${ }^{140}$ and development of a robust capital market, clear and reliable laws for fair play should be in place. ${ }^{141}$ Therefore, the legislation should categorically include, amongst others, auditors and attorneys ${ }^{142}$ as potentially liable persons facilitating smooth enforcement of the law.

Defences available appear to be very wide and therefore those should be revisited. For example, the gist of the defences in all the jurisdictions at hand implies that the accused can be punished only for wilful disclosure or nondisclosure in a prospectus. The U.S. Court of Appeal for the Ninth Circuit in this regard underscored the need for participation in the alleged offence in order to establish a prima facie case against the accused. ${ }^{143}$ A similar observation was made in Christoffel $v$. Hutton \& Company. ${ }^{144}$ In interpreting the term "willful" in the present context, ${ }^{145}$ the court in United States $v$.

139. Ian Tunstall, International Securities Regulation 459 (2005).

140. A number recent studies suggest that an appropriate legal regime providing protection to investors is very significant for the development of securities markets: For some those studies, see Rafael La Porta et al., What Works in Securities Law?, 61 J. Fin. 1 (2006); Rafael La Porta et al., INVESTOR Protection and Corporate Valuation, 57 J. Fin. 1147 (2002); Andre Shleifer \& Daniel Wolfenzon, Investor Protection and Equity Markets, 66 J. FIN. Econ. 3 (2002); Florencio Lopez-De-Silanes, The Politics of Legal Reforms, 2 Economia 91 (2002); Rafael La Porta et al., Investor Protection and Corporate Governance, 58 J. Fin. Econ. 3 (2000); Rafael La Porta et al., Agency Problems and Dividend Policies Around the World, 55 J. FIn. Econ. 1 (2000); Rafael La Porta et al., Corporate Ownership Around the World, 54 J. Fin. Econ. 471 (1999); Rafael La Porta et al., Law and Finance, 106 J. PoL. Econ. 1113 (1998); Rafael La Porta et al., Legal Determinants of External Finance, 52 J. Fin. 1131 (1998); Andre Shleifer \& Robert W. Vishny, A Survey of Corporate Governance, 52 J. Fin. 737 (1997).

141. Franco Modigliani \& Enrico Perotti, Protection of Minority Interest and the Development of Security Markets, 18 Managerial and Decision Econ. 519, 526 (1997).

142. A recommendation for the inclusion of lawyers, underwriters, issue manager as potentially liable persons will also be made in another study.

143. Kersh v. General Council of the Assemblies of God, 804 F.2d 546, 549 (9th Cir. 1986).

144. 588 F.2d 665, 668 (9th Cir. 1978).

145. The court interpreted the term "willfully" under § 32(a) of the Securities Exchange Act 1934, 15 U.S.C. $\S 77 \mathrm{ff}(\mathrm{a})$ (2006). This section is analogous to $\S 24$ of the Securities Act of 1933, 15 U.S.C. $\S 77$ a (2006). 
Schwartz said that a violation is wilful even if there is no "bad purpose" or no "specific intent to violate the law."146 In a similar context, the Court of Appeals of Arizona in State v. Tarzian construed the term "wilfully" by saying that:

. . when applied to the intent with which an act is done or omitted, implies simply a purpose or willingness to commit the act, or make the omission referred to. It does not require any intent to violate law, or injure another or to acquire any advantage. ${ }^{147}$

Despite such liberal interpretation of the term "wilful," the wilful requirement had been omitted in 1998 (under section 44-1992) from the Securities Act of Arizona 1951 in an identical context. Thus Arizona has made the criminal liability strict in 1998 without any defence therefore providing better protection to the investors. Thus it is submitted that the requirement of "willful commission of prospectus offences," in whatever term it is expressed, be omitted and that liability be imposed depending on the role played by an individual in the preparation of a prospectus. As discussed earlier, "the prospectus is a group effort: the collective work product of the issuer, its lawyers and accountants, and the underwriters (and their lawyers)." ${ }^{.18}$ In support of strict liability, it has been argued that "[i]t is impossible for an outsider to identify who is responsible for a particular statement in a prospectus." $" 149$

Interestingly, the post-Enron reforms taking place in the U.S., Australia and Canada are not clear enough in respect of their applicability to prospectuses. Judicial interpretations of their applicability to prospectuses are not available as of yet. Expert opinions differ. Some American experts are of the view that the SOX'02 applies to the prospectus regime as well, whilst some Australian experts opine that CLERPA'04 is not applicable to prospectus disclosures. But both the SOX'02 and the CLERPA'04 explicitly amend the laws governing corporate disclosure in the secondary securities market. Hence, it is recommended that respective legislatures should make it clear whether those reforms really affect their prospectus liability regimes, similar to the way their Canadian equivalent has been clearly made applicable to prospectuses.

146. 464 F.2d 499, 509-10 ( 2d Cir. 1972), cert. denied, 409 U.S. 1009 (1972).

147. 665 P.2d 582,585 (1983).

148. Brian Murray \& Donald J. Wallace, You Shouldn't Be Required to Plead More Than You Have to Prove, 53 BAYLoR L. Rev. 783, 800 (2001).

149. Id. 
As observed in the preceding discussions, some provisions are remarkably similar across jurisdictions; but some others are highly divergent. Incidentally the term of imprisonment is identical, but pecuniary penalties are significantly different. Given the similarity amongst these jurisdictions as alluded to earlier, provisions for equivalent fines may be introduced especially by increasing the fines enforceable in Australia. Commenting on the justification of stringent regulation of auditors, Birke maintains by making reference to the situation prevailing in the U.S. that audit is vital for a national economy and "audit's genesis lies in the Securities Acts." ${ }^{150}$ Supporting this view, Harrison argues that accountants and lawyers do not merely blow the whistle, they help the corporations commit the fraud. ${ }^{151}$ The existence of repeated corporate collapses over the years around the globe implies that the issue of regulation of auditors should not be left solely with their own professional body; rather, stringent legislation is needed. ${ }^{152}$ When the securities market was in "complete disarray" following the aftershock of the 1929 crash, Roosevelt's appeal to the U.S. Congress was to legislate a law that "puts the burden of telling the whole truth on the seller" of securities in order to "bring back investor confidence." 153 Since auditors and lawyers play a very significant role in telling that truth, securities laws should be strengthened in order to regulate auditors and lawyers effectively.

150. Birke, supra note 13 , at 920.

151. Harrison, supra note 46, at 537.

152. Tomasic, supra note 53, at 227-28.

153. Edward F. Greene, Determining the Responsibilities of Underwriters Distributing Securities Within an Integrated Disclosure System, 56 Notre Dame L. Rev. 756, 767 (1981), quoting H.R. ReP. No. 85 , at 2 (1933). 